Pohjola

numeroina

2012

ANP 2012:752 


\section{Pohjola numeroina 2012}

ISBN 978-92-893-2414-4

ISSN 0908-4339

http://dx.doi.org/10.6027/ANP2012-752

ANP 2012:752

(C) Pohjoismaiden ministerineuvosto 2012

Kansi: Jette Koefoed, Pohjoismaiden ministerineuvosto

Paino: Rosendahls-Schultz Grafisk, Albertslund

Painos: 2000

Printed in Denmark

Pääasialliset tietolähteet: Pohjoismaiden kansalliset tilastokeskukset.

Toimittajat: Klaus Munch Haagensen, Danmarks Statistik (Tanskan tilastokeskus). Tietokanta: Troels A. Vestergaard, Danmarks Statistik, (Tanskan tilastokeskus).

\section{Pohjoismaiden ministerineuvosto}

Nordisk Ministerråd

Ved Stranden 18

DK-1061 København K

Puh: +4533960200

www.norden.org

\section{Pohjoismainen yhteistyö}

Pohjoismainen yhteistyö on yksi maailman laajimpia alueellisia yhteistyömuotoja. Yhteistyön piiriin kuuluvat Islanti, Norja, Ruotsi, Suomi ja Tanska sekä Ahvenanmaa, Färsaaret ja Grönlanti.

Pohjoismaista yhteistyötä tehdään politiikan, talouden ja kulttuurin aloilla tärkeänä osana eurooppalaista ja kansainvälistä yhteistyötä. Pohjoismaisen yhteisön tavoitteena on vahva Pohjola vahvassa Euroopassa.

Pohjoismainen yhteistyö pyrkii vahvistamaan pohjoismaisia ja alueellisia etuja ja arvoja globaalissa maailmassa. Maiden yhteiset arvot lujittavat osaltaan Pohjolan asemaa yhtenä maailman innovatiivisimmista ja kilpailukykyisimmistä alueista. 


\section{Sisällys}

Pohjoismaat

Avainluvut

Maantiede ja ilmasto

Ympäristö ja energia

Väestö

Terveys

Sosiaalinen integraatio

Koulutus
4 Työmarkkinat $\quad 18$

6 Vaalit 20

8 Kulttuuri 21

9 Talous 22

10 Ulkomaankauppa 25

13 Julkinen talous ja hinnat 27

15 Tiede ja tekniikka 30 16

Taulukon tai kaavion alla oleva symboli viittaa lähteenä käytettyyn Nordic Statistics -tietokannan taulukkoon osoitteessa www.norden.org. Viite symbolin jälkeen toimii linkkinä tietokannan taulukkoon. Taulukko avautuu viitettä napsauttamalla.

Kirjassa käytetään seuraavia symboleja ja maakoodeja:

\section{Symbolit}

Ei yhtään

Vähemmän kuin puolet 0

Tieto ei ole

sovellet-tavissa

Tieto puuttuu

\section{Maakoodit}

Tanska; DK

Färsaaret: FO

Grönlanti: GL

Suomi: FI
Ahvenanmaa: AX

Islanti: IS

Norja: NO

Ruotsi: SE

Kuvissa maita kuvaavat seuraavat värit:

Tanska:

Grönlanti:

Färsaaret:
Suomi:
Ahvenanmaa:

Islanti:
Norja:

Ruotsi: 


\section{Pohjoismaat}
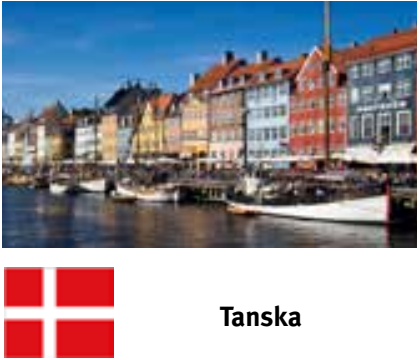

Pinta-ala $\mathrm{km}^{2}$

Asukasluku

Valtiomuoto

Valtionpäämies

Kööpenhamina

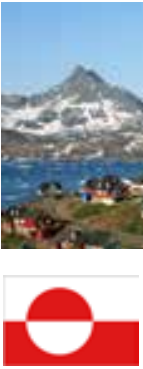

Pinta-ala $\mathrm{km}^{2}$

Asukasluku

Valtiomuoto

Valtionpäämies

Nuuk
Kuningatar Margareeta II

1213822

\section{Tanska}

43561

5580516

Perustuslaillinen

\section{Grönlanti}

2166086

56749

Itsehallinto, osa

Tanskan kuningaskuntaa

Kuningatar

Margareeta II

16181 kuningaskunta
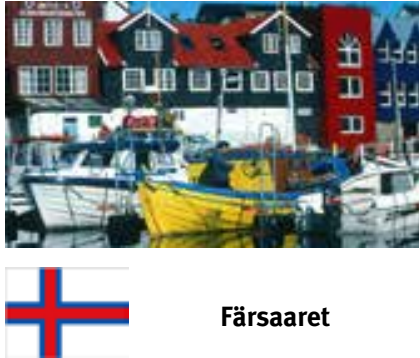

Pinta-ala km²

1396

Asukasluku

48351

Valtiomuoto

Itsehallinto, osa

Tanskan kuningas-

kuntaa

Valtionpäämies

Kuningatar

Margareeta II

Tórshavn

19834
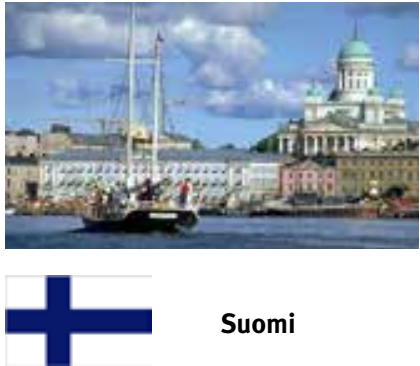

Suomi

Pinta-ala km²

338432

Asukasluku

5401267

Valtiomuoto

Tasavalta

Presidentti

Sauli Niinistö

Helsinki

1059631 

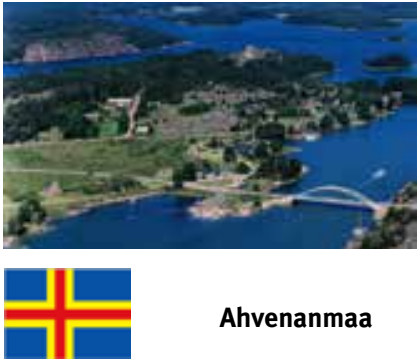

Pinta-ala km²

Asukasluku

Valtiomuoto

Valtionpäämies

Maarianhamina
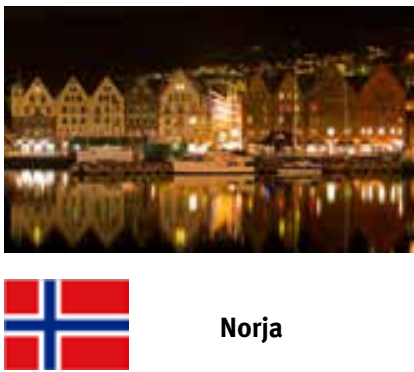

Pinta-ala km

Asukasluku

Valtiomuoto

Valtionpäämies

Oslo

\section{Ahvenanmaa}

1580

28355

Itsehallinto, osa

Suomen tasavaltaa

Presidentti

Sauli Niinistö

11263

Norja

323787

4985870

Perustuslaillinen kuningaskunta

Kuningas Harald V

1169539
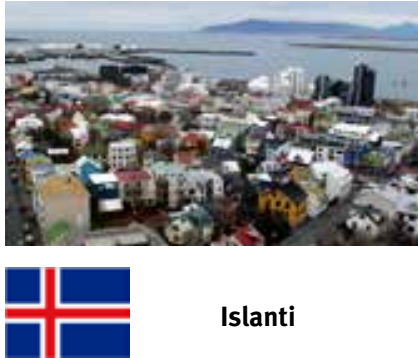

Islanti

Pinta-ala km²

103440

Asukasluku

319575

Valtiomuoto

Tasavalta

Valtionpäämies

Presidentti Ólafur Ragnar Grímsson

Reykjavik 203594
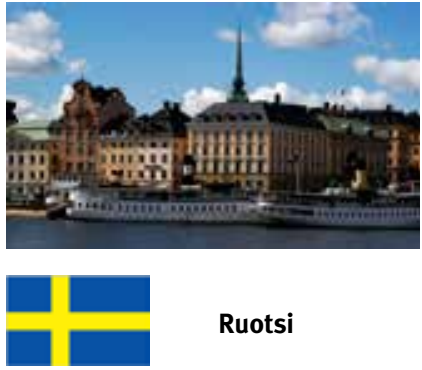

Pinta-ala km²

Asukasluku

Valtiomuoto

Valtionpäämies

Tukholma

\section{Ruotsi}

450295

9482855

Perustuslaillinen kuningaskunta

Kuningas Kaarle XVI Kustaa

2091473 
Pohjoismaat kansainvälisissä yhteyksissä - avainluvut $2011^{1}$

\begin{tabular}{|c|c|c|c|c|}
\hline & $\begin{array}{r}\text { Pohjois- } \\
\text { maat }\end{array}$ & $\begin{array}{c}\text { Euro- } \\
\text { alue }\end{array}$ & $\begin{array}{l}\text { Yhdys- } \\
\text { vallat }\end{array}$ & Japan \\
\hline \multicolumn{5}{|l|}{ Pinta-ala, $1000 \mathrm{~km}^{2}$} \\
\hline Kokonaispinta-ala & 3429 & 2628 & 9827 & 378 \\
\hline Jäätön pinta-ala & 1606 & 2552 & 9162 & 364 \\
\hline \multicolumn{5}{|l|}{ Väkiluku } \\
\hline Yhteensä, miljoonaa & 26 & 333 & 314 & 128 \\
\hline Asukkaita $/ \mathrm{km}^{2}$ & 16 & 130 & 34 & 350 \\
\hline \multicolumn{5}{|l|}{ Hedelmällisyys } \\
\hline Lasten määrä naista kohti & 1,9 & 1,6 & 2,1 & 1,3 \\
\hline \multicolumn{5}{|l|}{ Prosenttia väestöstä } \\
\hline 0-14-vuotiaita & 17,3 & 15,4 & 20,1 & 13,3 \\
\hline Yli 65-vuotiaita & 17,4 & 18,3 & 13,1 & 22,7 \\
\hline \multicolumn{5}{|l|}{ Keskimääräinen elinikä } \\
\hline Miehet & 78,5 & 78,0 & 76,2 & 79,6 \\
\hline Naiset & 83,1 & 83,7 & 81,1 & 86,4 \\
\hline \multicolumn{5}{|l|}{$B K T$} \\
\hline Miljardia euroa & 1088 & 9413 & 10830 & 4220 \\
\hline Henkeä kohti euroissa (PPP) & 34400 & 27100 & 37100 & 27000 \\
\hline \multicolumn{5}{|l|}{ Julkinen sektori, \% BKT:sta } \\
\hline Velat v. 2009 lopussa & 45,0 & 85,1 & 61,3 & 183,5 \\
\hline Ylijäämä & 0,4 & $-6,0$ & $-10,7$ & $-8,7$ \\
\hline Verot 2008 & 44,9 & 38,9 & 24,0 & 28,1 \\
\hline \multicolumn{5}{|l|}{ Työvoima } \\
\hline \multicolumn{5}{|l|}{ Työvoimaosuus, \% } \\
\hline Miehet & 81,6 & 79,1 & 78,9 & 84,5 \\
\hline Naiset & 76,4 & 66,5 & 67,8 & 63,0 \\
\hline Työttömyysprosentti & 6,7 & 10,1 & 8,9 & 4,6 \\
\hline
\end{tabular}

${ }^{1} 2011$ tai uusin saatavilla oleva luku. Pohjoismaat käsittävät Islannin, Norjan, Ruotsin, Suomen, Tanskan, Ahvenanmaan, Färsaaret ja Grönlannin. Euroalue tarkoittaa niitä 17:ää maata, joiden valuutta on euro. 


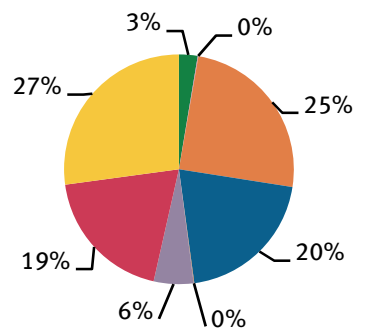

- Tanska 3\%

n Färsaaret $<0 \%$

Grönlanti 25\%

- Suomi $20 \%$

- Ahvenanmaa $<0 \%$

- Islanti $6 \%$

- Norja $19 \%$

Ruotsi $27 \%$

$\square$ Area02

\section{Väestö}

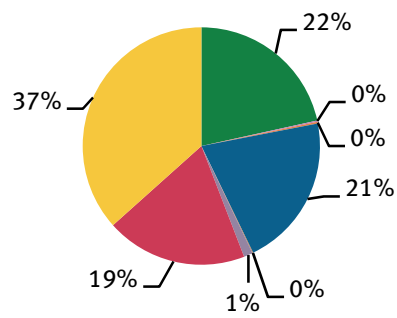

- Tanska 22\%

- Färsaaret < $0 \%$

- Grönlanti < $0 \%$

- Suomi 21\%

Ahvenanmaa $<0 \%$

- Islanti $1 \%$

- Norja $19 \%$

Ruotsi $37 \%$

몽 Popu01

\section{Bruttokansantulo}

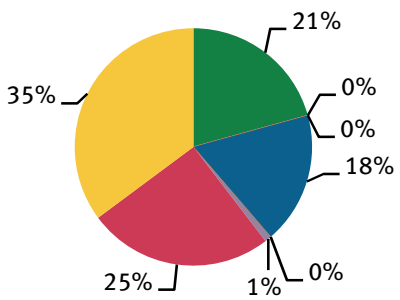

- Tanska 21\%

- Färsaaret $<0 \%$

- Grönlanti < $0 \%$

- Suomi $18 \%$

- Ahvenanmaa $<0 \%$

- Islanti $1 \%$

- Norja $25 \%$

Ruotsi 35\% 
Maantiede ja ilmasto

\section{Maankäyttö 2011}

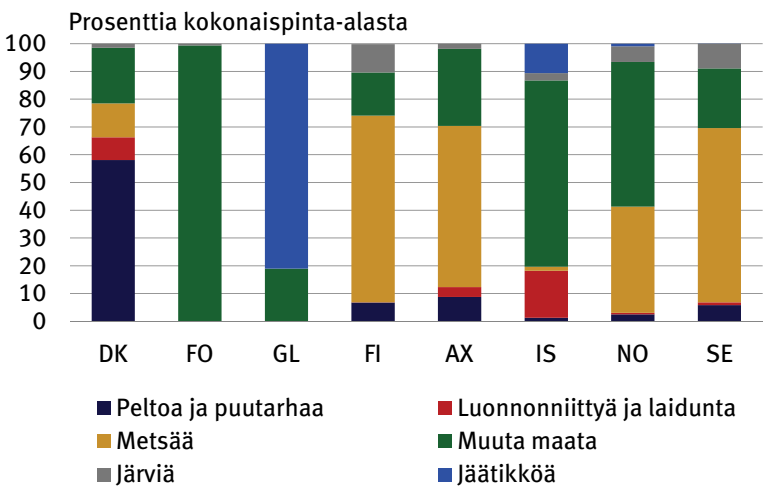

$\square$ Area02

\section{Pohjoismaiden pääkaupunkien keskilämpötila}

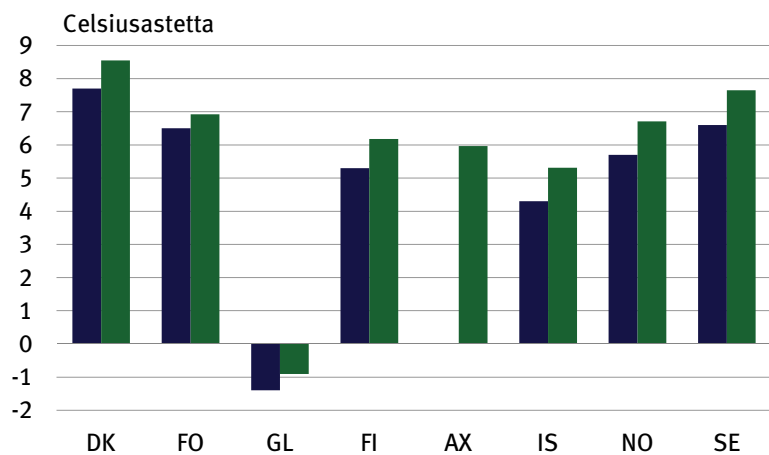

— Keskilämpötila 1961-1990 Keskilämpötila 1990-2011 


\section{Kasvihuonekaasupäästöt asukasta kohden}

\begin{tabular}{crrrrr} 
& DK & FI & IS & NO & SE \\
\hline CO $_{2}$-ekvivalentit, tonnia & & & & & \\
\hline 1990 & 13,6 & 14,1 & 13,7 & 11,7 & 8,5 \\
1995 & 14,8 & 13,8 & 12,2 & 11,4 & 8,4 \\
2000 & 13,0 & 13,4 & 13,7 & 11,9 & 7,8 \\
2005 & 12,0 & 13,1 & 12,9 & 11,6 & 7,5 \\
2010 & 11,3 & 13,9 & 14,3 & 11,0 & 7,1 \\
\hline
\end{tabular}

Emis11 ja Popu02

Energiantuotanto, miljoonaa ekvivalenttiöljytonnia 2010

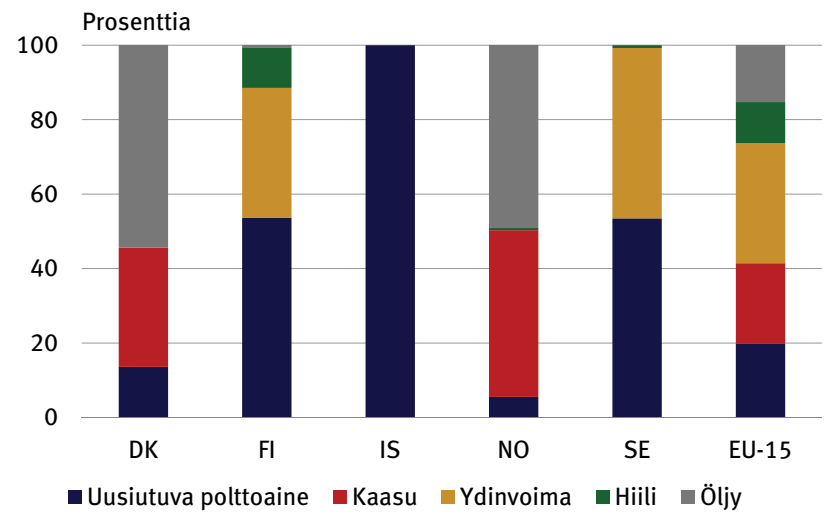

믈 Ener06. EU-15 = EU:n jäsenmaat 1. päivänä tammikuuta 1995: Itävalta, Belgia, Tanska, Saksa, Suomi, Kreikka, Espanja, Ranska, Irlanti, Italia, Luxemburg, Alankomaat, Portugali, Ruotsi ja Yhdistynyt kuningaskunta. 
Väestö

Pohjoismaiden väkiluku 1.1.2011

\begin{tabular}{lrrr}
\hline & Yhteensä & Miehet & Naiset \\
\hline Pohjoismaat yht. & $\mathbf{2 5 8 7 5 \mathbf { 1 8 3 }}$ & $\mathbf{1 2 8 6 0 5 3 4}$ & $\mathbf{1 3 2 0 1 4 6 4 9}$ \\
Tanska & 5580516 & 2766776 & 2813740 \\
Färsaaret & 48351 & 25114 & 23237 \\
Grönlanti & 56749 & 30041 & 26708 \\
Suomi & 5401267 & 2652534 & 2748733 \\
Ahvenanmaa & 28355 & 14136 & 14219 \\
Islanti & 319575 & 160364 & 159211 \\
Norja & 4985870 & 2498871 & 2486999 \\
Ruotsi & 9482855 & 4726834 & 4756021 \\
\hline
\end{tabular}

$\square$ Popu01. Suomen väkiluku sisältää Ahvenanmaan väestön.

\section{Väestöennusteet}

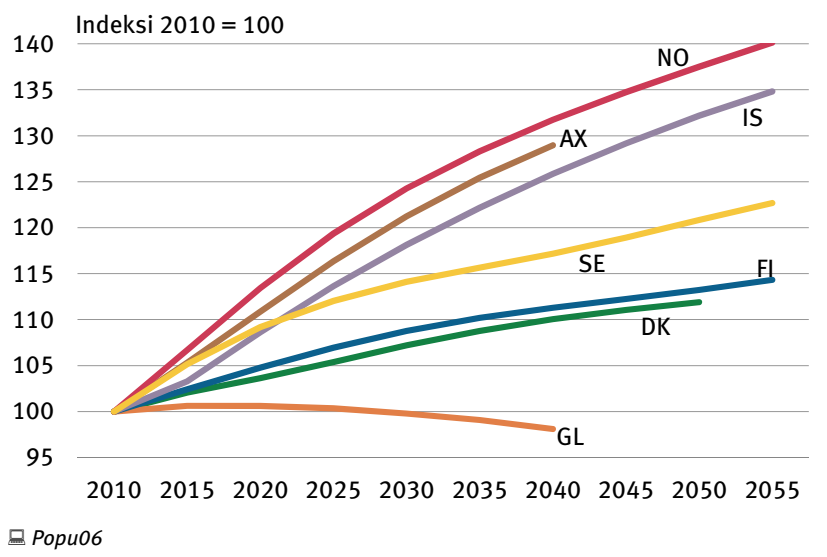




\section{Kokonaishedelmällisyysluvut}

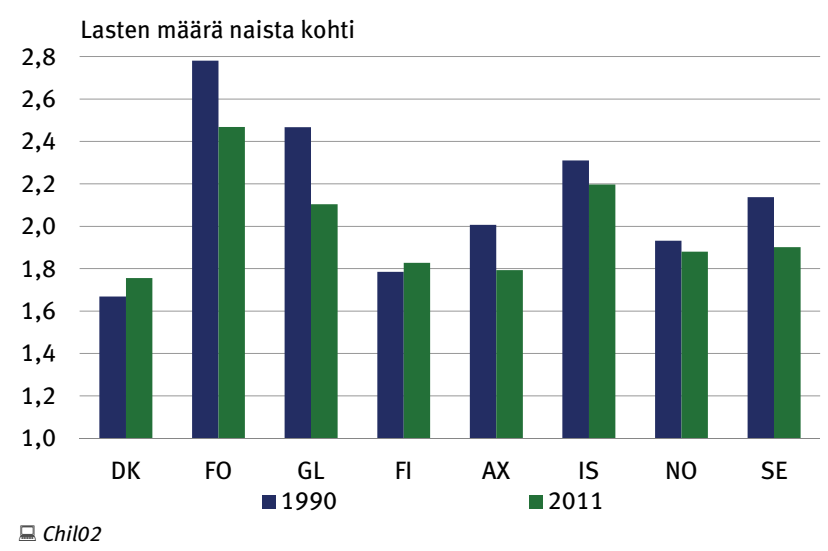

Elinajanodote 0-vuotiaana, vuosia

$\begin{array}{llllllll}\text { DK } & \text { FO } & \text { GL } & \text { FI } & \text { AX } & \text { IS } & \text { NO } & \text { SE }\end{array}$

Miehet

\begin{tabular}{lrrrrrrrr}
\hline 1990 & 72,0 & 73,1 & 60,7 & 70,9 & 74,7 & 75,0 & 73,4 & 74,8 \\
1995 & 72,6 & 74,5 & 62,3 & 72,8 & 75,1 & 76,5 & 74,8 & 76,2 \\
2000 & 74,3 & 76,2 & 62,8 & 74,1 & 78,5 & 77,6 & 76,0 & 77,4 \\
2005 & 75,6 & 77,2 & 65,5 & 75,5 & 77,6 & 79,2 & 77,7 & 78,4 \\
2010 & 77,1 & 78,7 & 67,9 & 76,7 & 81,2 & 79,5 & 78,9 & 79,5 \\
2011 & 77,3 & 79,1 & 68,3 & 77,2 &.. & 79,9 & 79,0 & 79,8 \\
& & & & & & & & \\
Naiset & & & & & & & & \\
1990 & 77,7 & 80,3 & 68,4 & 78,9 & 82,8 & 80,1 & 79,8 & 80,4 \\
1995 & 77,8 & 81,3 & 68,3 & 80,2 & 81,1 & 80,6 & 80,8 & 81,5 \\
2000 & 79,0 & 81,6 & 68,0 & 81,0 & 81,5 & 81,4 & 81,4 & 82,0 \\
2005 & 80,2 & 82,2 & 70,9 & 82,3 & 83,6 & 83,1 & 82,5 & 82,8 \\
2010 & 81,2 & 84,4 & 72,9 & 83,2 & 84,2 & 83,5 & 83,2 & 83,5 \\
2011 & 81,6 & 84,9 & 73,0 & 83,5 &.. & 83,6 & 83,5 & 83,7 \\
\hline
\end{tabular}

믄 Life01 
Väestö

Turvapaikanhakijat

\begin{tabular}{lrrrrrr}
\hline & DK & FI & IS & NO & SE & $\begin{array}{r}\text { Pohjois- } \\
\text { maat yht. }\end{array}$ \\
\hline 1990 & 5292 &.. & 4 &.. & 29420 &.. \\
1995 & 5104 &.. & 4 & 1460 & 9047 &. \\
2000 & 10347 & 3170 & 25 & 10843 & 16303 & 40688 \\
2005 & 1283 & 3574 & 87 & 5402 & 17530 & 27876 \\
2006 & 922 & 2324 & 39 & 5320 & 24322 & 32927 \\
2007 & 1029 & 1505 & 42 & 6528 & 36207 & 45311 \\
2008 & 951 & 4035 & 73 & 14431 & 24353 & 43843 \\
2009 & 2022 & 5988 & 34 & 17226 & 24194 & 49464 \\
2010 & 2844 & 4018 & 44 & 10064 & 31819 & 48789 \\
2011 & 3573 & 3087 & 75 & 9053 & 29670 & 45458 \\
\hline Migr04 & & & & & &
\end{tabular}

\section{Nettomaahanmuutto}

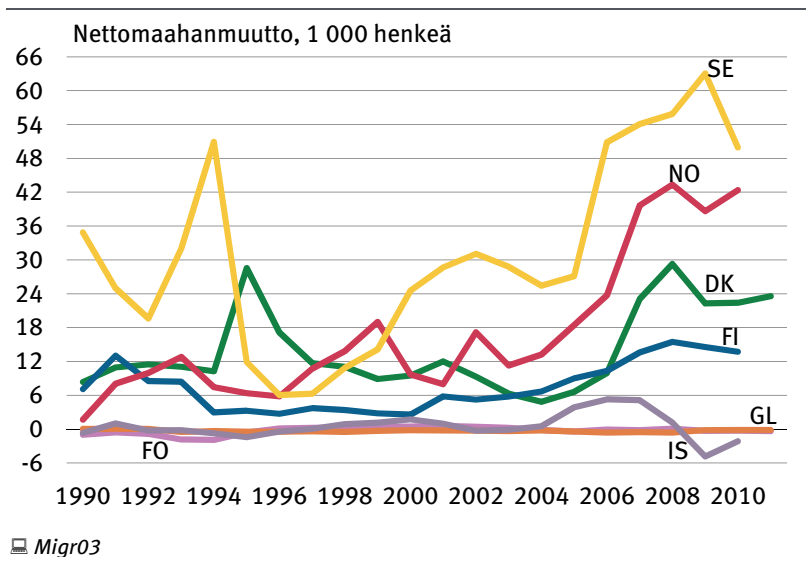


Päivittäin tupakoivat

$\begin{array}{llllll}\text { DK } & \text { FO } & \text { FI } & \text { IS } & \text { NO } & \text { SE }\end{array}$

Prosenttia

Miehet

\begin{tabular}{lllllll}
\hline 1995 & 44 &.. & 29 & 32 & 33 & 22 \\
2000 & 31 &.. & 27 & 23 & 31 & 17 \\
2005 & 28 & 28 & 26 & 20 & 27 & 14 \\
2009 & 24 & 24 & 22 & 15 & 21 & 13 \\
Naiset & & & & & & \\
\hline 1995 & 39 &.. & 19 & 33 & 32 & 24 \\
2000 & 26 &.. & 20 & 22 & 32 & 21 \\
2005 & 23 & 27 & 18 & 20 & 24 & 18 \\
2009 & 22 & 24 & 14 & 16 & 20 & 15 \\
\hline
\end{tabular}

믈eal01

\section{Alkoholijuomien myynti}

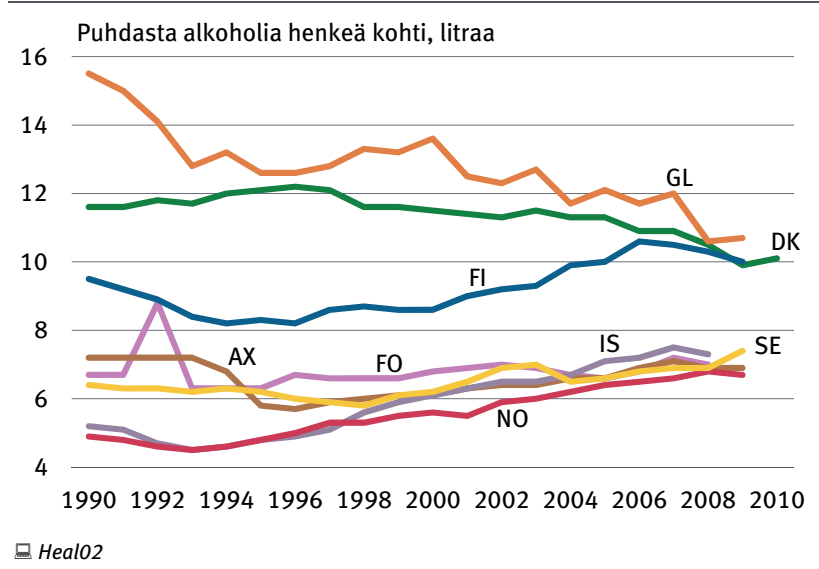


Kuolemansyyt 100 000:aa asukasta kohti

\begin{tabular}{|c|c|c|c|c|c|c|c|c|}
\hline & DK & FO & GL & Fl & AX & IS & NO & SE \\
\hline \multicolumn{9}{|l|}{ Miehet } \\
\hline \multicolumn{9}{|l|}{2005} \\
\hline Syöpä & 300 & 206 & 218 & 215 & 310 & 193 & 224 & 256 \\
\hline \multicolumn{9}{|l|}{$\begin{array}{l}\text { Sydän- ja } \\
\text { verisuoni- }\end{array}$} \\
\hline sairaudet & 303 & 335 & 185 & 364 & 338 & 226 & 300 & 418 \\
\hline Itsemurha & 17 & 12 & 89 & 28 & 23 & 16 & 16 & 19 \\
\hline Tapaturmat & 35 & 37 & 82 & 81 & 43 & 26 & 50 & 44 \\
\hline \multicolumn{9}{|l|}{2009} \\
\hline Syöpä & 281 & 182 & 208 & 222 & 279 & 192 & 234 & 245 \\
\hline \multicolumn{9}{|l|}{$\begin{array}{l}\text { Sydän- ja } \\
\text { verisuoni- }\end{array}$} \\
\hline sairaudet & 259 & 261 & 131 & 376 & 332 & 236 & 257 & 374 \\
\hline Itsemurha & 17 & 8 & 100 & 29 & 12 & 18 & 17 & 19 \\
\hline Tapaturmat & 28 & 63 & 60 & 74 & 61 & 25 & 45 & 37 \\
\hline \multicolumn{9}{|l|}{ Naiset } \\
\hline \multicolumn{9}{|l|}{2005} \\
\hline Syöpä & 276 & 212 & 225 & 189 & 198 & 152 & 213 & 227 \\
\hline \multicolumn{9}{|l|}{$\begin{array}{l}\text { Sydän- ja } \\
\text { verisuoni- }\end{array}$} \\
\hline sairaudet & 322 & 334 & 188 & 389 & 455 & 217 & 328 & 436 \\
\hline Itsemurha & 6 & 1 & 86 & 10 & 5 & 6 & 7 & 8 \\
\hline Tapaturmat & 27 & 19 & 53 & 36 & 17 & 18 & 34 & 31 \\
\hline \multicolumn{9}{|l|}{2009} \\
\hline Syöpä & 259 & 201 & 227 & 191 & 242 & 160 & 203 & 222 \\
\hline \multicolumn{9}{|l|}{$\begin{array}{l}\text { Sydän- ja } \\
\text { verisuoni- }\end{array}$} \\
\hline sairaudet & 271 & 244 & 136 & 386 & 400 & 221 & 301 & 403 \\
\hline Itsemurha & 5 & 1 & 27 & 10 & 13 & 4 & 7 & 8 \\
\hline Tapaturmat & 23 & 13 & 38 & 33 & 21 & 16 & 35 & 25 \\
\hline
\end{tabular}

$\square$ Heal03, Heal04, Heal05 ja Heal07 
Sosiaalinen integraatio

Lapset päivähoidossa ikäryhmittäin 2011

\begin{tabular}{|c|c|c|c|c|c|c|c|}
\hline & DK & FO & FI & $\mathbf{A X}$ & IS & NO & SE \\
\hline \multicolumn{8}{|c|}{ Päivähoidossa olevien lasten kokonaismäärä ikäryhmittäin } \\
\hline Yhteensä & 82,7 & 78,5 & 50,0 & 59,6 & 74,6 & 76,2 & 72,0 \\
\hline $0 \mathrm{ve}$ & 18,9 & 16,8 & 1,0 & & 6,8 & 4,3 & 0,0 \\
\hline $1 \mathrm{v}$. & 89,4 & 83,5 & 29,8 & 24,9 & 65,9 & 70,6 & 49,3 \\
\hline $2 \mathrm{v}$. & 91,7 & 86,9 & 51,4 & 55,0 & 93,6 & 89,0 & 91,4 \\
\hline $3 \mathrm{v}$. & 97,9 & 92,1 & 68,0 & 78,9 & 95,5 & 96,7 & 96,1 \\
\hline $4 \mathrm{v}$. & 97,2 & 89,3 & 74,0 & 93,4 & 96,7 & 97,3 & 97,7 \\
\hline $5 \mathrm{v}$. & 97,2 & 96,5 & 78,2 & 92,4 & 93,8 & 98,9 & 98,3 \\
\hline
\end{tabular}

․․․ Chil03. Lapset, jotka ovat kokonaan tai osittain julkisesti rahoitetussa päivähoidossa.

Vanhempainpäivärahapäivät 2010

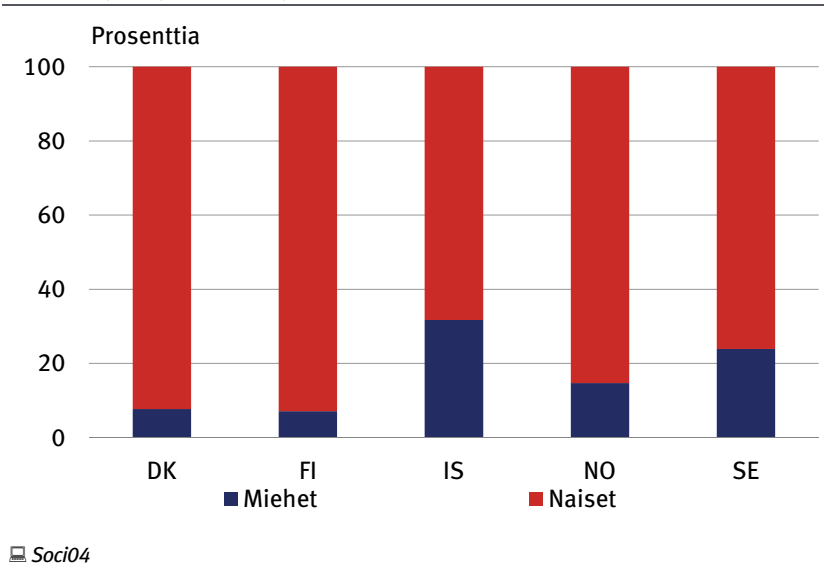


Opiskelijoiden osaaminen, PISA 2009

\begin{tabular}{|c|c|c|c|c|c|}
\hline Lukutaito & & $\begin{array}{l}\text { Matematiikan } \\
\text { osaaminen }\end{array}$ & & $\begin{array}{l}\text { Luonnontieteen } \\
\text { osaaminen }\end{array}$ & \\
\hline Etelä-Korea & 539 & Etelä-Korea & 546 & Suomi & 554 \\
\hline Suomi & 536 & Suomi & 541 & Japani & 539 \\
\hline Ahvenanmaa & 527 & Ahvenanmaa & 536 & Ahvenanmaa & 539 \\
\hline Kanada & 524 & Sveitsi & 534 & Etelä-Korea & 538 \\
\hline Uusi-Seelanti & 521 & Japani & 529 & Uusi-Seelanti & 532 \\
\hline Japani & 520 & Kanada & 527 & Kanada & 529 \\
\hline Australia & 515 & Alankomaat & 526 & Viro & 528 \\
\hline Alankomaat & 508 & Uusi-Seelanti & 519 & Australia & 527 \\
\hline Belgia & 506 & Belgia & 515 & Alankomaat & 522 \\
\hline Norja & 503 & Australia & 514 & Saksa & 520 \\
\hline Viro & 501 & Saksa & 513 & Sveitsi & 517 \\
\hline Sveitsi & 501 & Viro & 512 & Yhd. kuningask. & 514 \\
\hline Puola & 500 & Islanti & 507 & Slovenia & 512 \\
\hline Islanti & 500 & Tanska & 503 & Puola & 508 \\
\hline Yhdysvallat & 500 & Slovenia & 501 & Irlanti & 508 \\
\hline Ruotsi & 497 & Norja & 498 & Belgia & 507 \\
\hline Saksa & 497 & Ranska & 497 & Unkari & 503 \\
\hline Irlanti & 496 & Slovakia & 497 & Yhdysvallat & 502 \\
\hline Ranska & 496 & Itävalta & 496 & OECD & 501 \\
\hline Tanska & 495 & OECD & 496 & Tšekki & 500 \\
\hline Yhd. kuningask. & 494 & Puola & 495 & Norja & 500 \\
\hline Unkari & 494 & Ruotsi & 494 & Tanska & 499 \\
\hline OECD & 493 & Tšekki & 493 & Ranska & 498 \\
\hline Portugali & 489 & Yhd. kuningask. & 492 & Islanti & 496 \\
\hline Italia & 486 & Unkari & 490 & Ruotsi & 495 \\
\hline Slovenia & 483 & Luxemburg & 489 & Itävalta & 494 \\
\hline Kreikka & 483 & Yhdysvallat & 487 & Portugali & 493 \\
\hline Espanja & 481 & Irlanti & 487 & Slovakia & 490 \\
\hline Tšekki & 478 & Portugali & 487 & Italia & 489 \\
\hline Slovakia & 477 & Espanja & 483 & Espanja & 488 \\
\hline Israel & 474 & Italia & 483 & Luxemburg & 484 \\
\hline Luxemburg & 472 & Kreikka & 466 & Kreikka & 470 \\
\hline Itävalta & 470 & Färsaaret & 448 & Israel & 455 \\
\hline Turkki & 464 & Israel & 447 & Turkki & 454 \\
\hline Chile & 449 & Turkki & 445 & Chile & 447 \\
\hline Färsaaret & 436 & Chile & 421 & Färsaaret & 431 \\
\hline Meksiko & 425 & Meksiko & 419 & Meksiko & 416 \\
\hline
\end{tabular}


Yliopisto- ja korkeakouluopiskelijat, prosenttia kaikista 20-39-vuotiaista 22 Prosenttia kaikista 20-39-vuotiaista

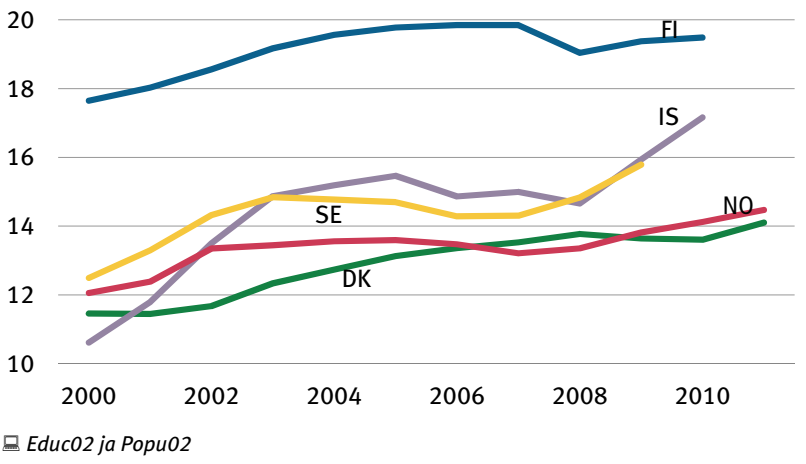

Pohjoismaiset opiskelijat ulkomailla opiskelumaan mukaan 2010/2011

\begin{tabular}{lrrrrrr} 
Kotimaa & DK & FI & AX & IS & NO & SE \\
\hline Yhteensä & $\mathbf{3 8 5}$ & $\mathbf{5 4 5 7}$ & $\mathbf{1 0 5 8}$ & $\mathbf{2 4 0 6}$ & $\mathbf{1 5} \mathbf{1 6 9}$ & $\mathbf{2 1} \mathbf{7 0 5}$ \\
\hline $\begin{array}{l}\text { Opiskelumaa: } \\
\text { Pohjoismaat, yhteensä }\end{array}$ & $\mathbf{6 1 4}$ & $\mathbf{1 1 7 8}$ & $\mathbf{1 0 1 5}$ & $\mathbf{1 3 0 7}$ & $\mathbf{4 0 8 7}$ & $\mathbf{3 1 2 1}$ \\
Tanska & $\mathbf{1 0}$ & 133 & 6 & 1058 & 2938 & 2117 \\
Suomi & 16 &. & 228 & $\mathbf{3}$ & 37 & 215 \\
Islanti & 46 & 13 & 1 &. & 34 & 26 \\
Norja & 189 & 76 & 6 & 66 &. & 763 \\
Ruotsi & 363 & 956 & 774 & 180 & 1078 & \\
Ranska & 69 & 101 & - & 23 & 322 & 832 \\
Saksa & 198 & 263 & 2 & 61 & 207 & 656 \\
Yhdistynyt & & & & & & \\
kuningaskunta & 1478 & 1777 & 17 & 247 & 3552 & 4484 \\
Yhdysvallat & 307 & 370 & 8 & 324 & 1264 & 4110 \\
Muut & 719 & 1768 & 16 & 444 & 5737 & 8502 \\
\hline
\end{tabular}




\section{Työmarkkinat}

\section{Työvoima sukupuolen mukaan 2011}

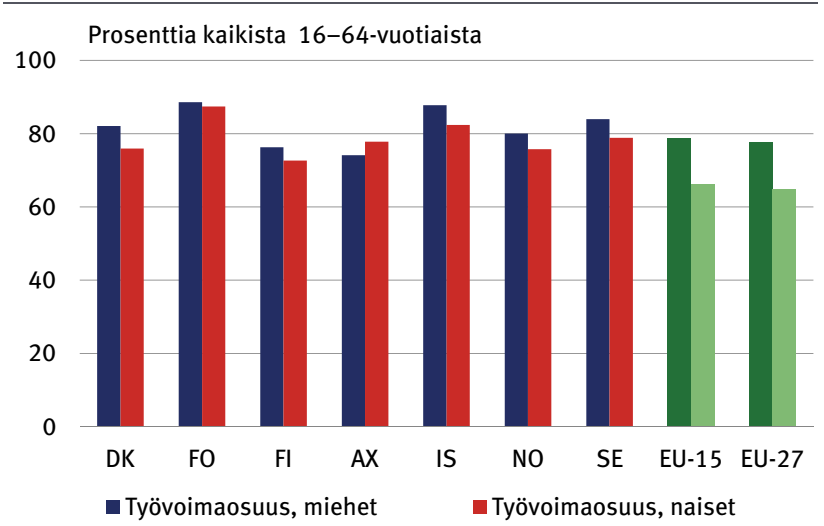

Work02. EU-27 = EU-15 + Bulgaria, Kypros, Viro, Latvia, Liettua, Malta, Puola, Romania, Slovenia, Slovakia, Tsekki ja Unkari.

\section{Työttömyys}

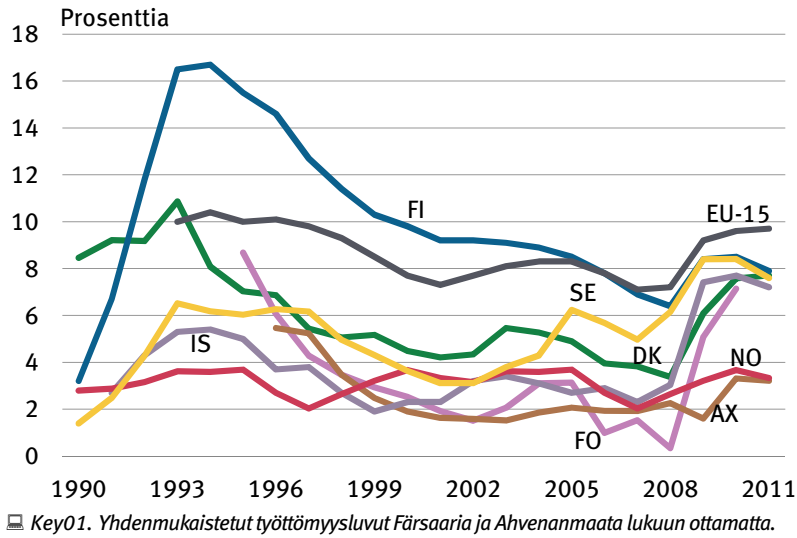


Työttömyys ikäryhmittäin 2011

\begin{tabular}{|c|c|c|c|c|c|c|c|}
\hline & DK & FO & FI & $\mathbf{A X}$ & IS & NO & SE \\
\hline \multicolumn{8}{|c|}{ Prosenttia työvoimasta } \\
\hline Yhteensä & 7,7 & 7,1 & 7,9 & 3,2 & 7,2 & 3,3 & 7,6 \\
\hline $16-19 v$ & 17,2 & 27,3 & 29,6 & 11,8 & 17,4 & 11,5 & 34,2 \\
\hline $20-24 \mathrm{v}$. & 11,9 & 12,0 & 16,0 & 6,8 & 12,6 & 7,2 & 18,2 \\
\hline $25-34 \mathrm{v}$ & 9,7 & 6,7 & 7,5 & 3,2 & 8,6 & 4,0 & 7,2 \\
\hline $35-44 \mathrm{v}$. & 5,5 & 3,1 & 5,5 & 1,8 & 4,0 & 2,3 & 4,8 \\
\hline $45-54 \mathrm{v}$ & 5,3 & 2,6 & 5,6 & 3,0 & 4,5 & 2,1 & 4,6 \\
\hline $55-64 \mathrm{v}$. & 5,7 & 4,8 & 6,4 & 3,1 & 5,4 & 1,2 & 4,7 \\
\hline
\end{tabular}

$\square$ Work02

\section{Osa-aikatyö sukupuolen mukaan 2011}

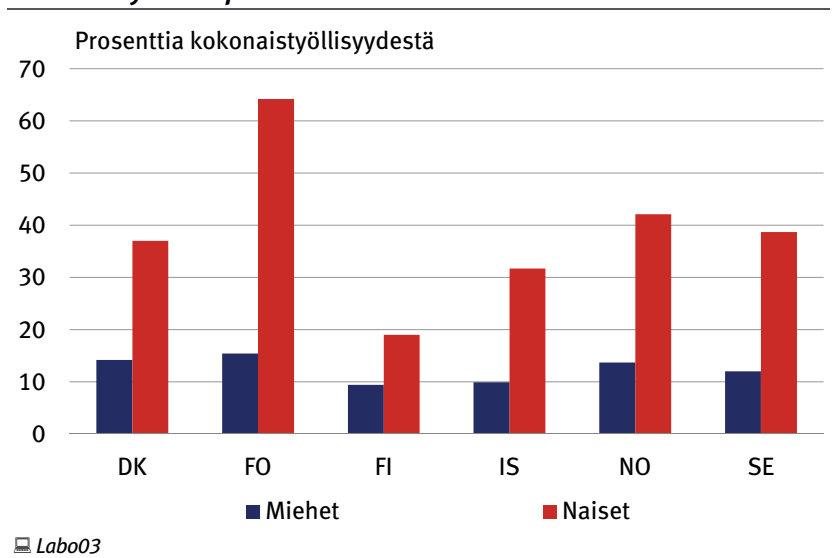


Vaalit

Hyväksytyt äänet kaksissa viimeisimmissä kansallisissa vaaleissa

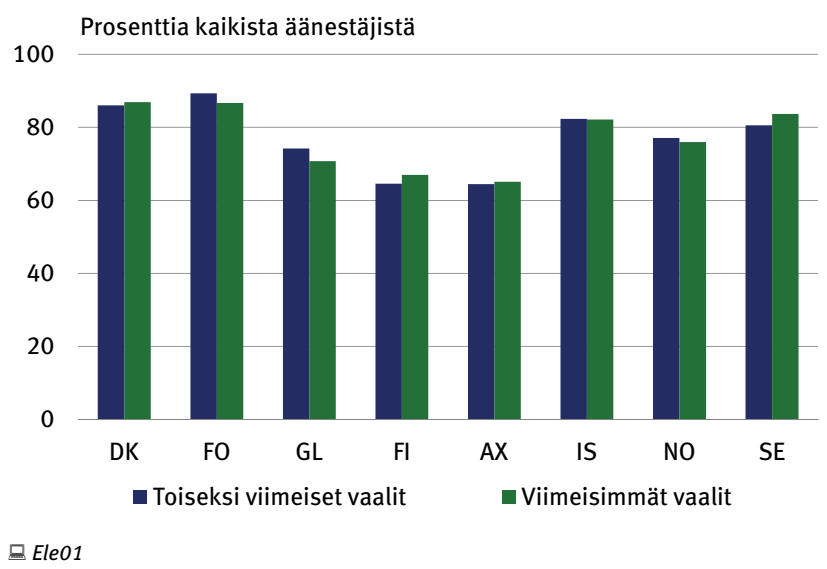

Kansallisiin parlamentteihin valitut, viimeisimmät vaalit

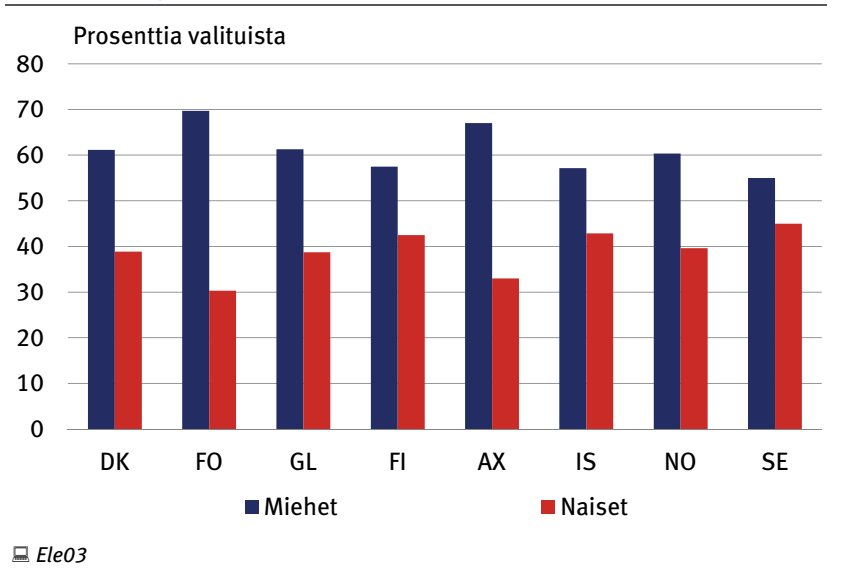


Kulttuuri

Musiikin myynti 2011

\begin{tabular}{|c|c|c|c|c|c|}
\hline & DK & FI & IS & NO & SE \\
\hline \multicolumn{6}{|l|}{1000 euroa } \\
\hline Kokonaismyynti & 56451 & 33139 & 4206 & 64911 & 92983 \\
\hline $\begin{array}{l}\text { Digitaalinen } \\
\text { myynti }\end{array}$ & 22043 & 8174 & 124 & 17883 & 47568 \\
\hline \multicolumn{6}{|l|}{ Prosenttia } \\
\hline $\begin{array}{l}\text { Kokonaismyynti } \\
\text { Digitaalinen }\end{array}$ & 100 & 100 & 100 & 100 & 100 \\
\hline
\end{tabular}

\footnotetext{
Cult19
}

\section{Museokäynnit 2011}

Käyntejä henkeä kohti

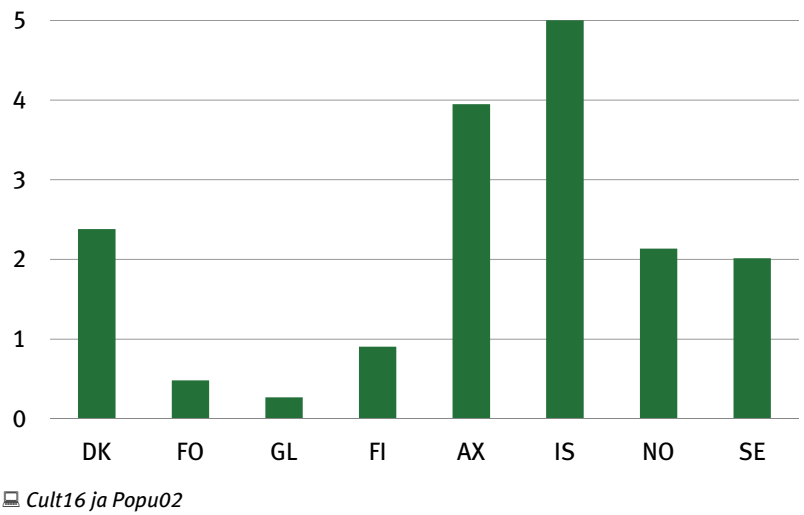


Talous

Pohjoismaiden ja euroalueen talouden avainluvut 2010

DK FI IS NO SE $\begin{array}{r}\begin{array}{r}\text { Euro- } \\ \text { alue }\end{array} \\ \text {. }\end{array}$

Prosenttia BKT:sta

Vaihtotaseen ylijäämä

$\begin{array}{llllll}5,6 & 3,1 & -7,8 & 13,7 & 6,4 & 0,7\end{array}$

Ulkomaiset saamiset

(netto), 31.12.2010

$\begin{array}{llllll}10,0 & 8,9 & -605,8 & 104,4 & -24,2 & \text {.. }\end{array}$

Julkisen talouden

ylijäämä

$\begin{array}{llllll}-2,7 & -2,5 & -7,8 & 10,5 & 0,0 & -6,0\end{array}$

Julkisen talouden

velka, 31.12.2010

$\begin{array}{llllll}43,6 & 48,4 & 89,5 & 44,7 & 39,8 & 85,1\end{array}$

Prosenttia

Työttömyys

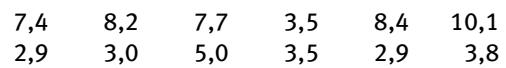

Korko

Muutos 2009-2010, prosenttia

Kuluttajahintojen

nousu

$2,2 \quad 1,7 \quad 7,5 \quad 2,3 \quad 1,9 \quad 1,6$

Taloudellinen kasvu

$\begin{array}{llllll}1,7 & 3,6 & -3,5 & 0,3 & 5,7 & 1,8\end{array}$

Osakekurssi-indeksi

$\begin{array}{llllll}33,2 & 21,5 & 21,9 & 26,6 & 30,5 & 13,5\end{array}$

Nimellinen efektiivinen

valuuttakurssi-indeksi

$\begin{array}{lllll}-3,6 & -5,7 & . . & 4,7 & 7,0\end{array}$

Key01. Työttömyysluvut on yhdenmukaistettu. Euroalue tarkoittaa niitä 17:ää maata, joiden valuutta on euro. 


\section{Kiinteistöjen hinnat}

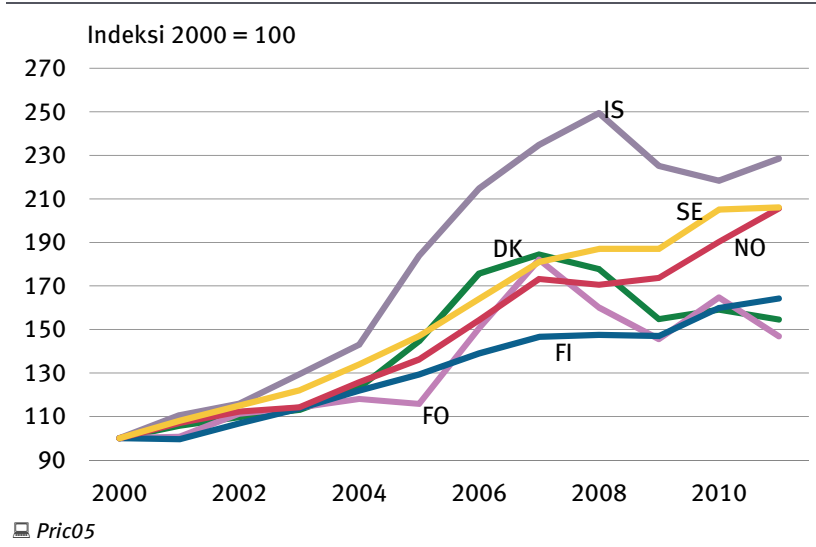

\section{Suorat sijoitukset ulkomailta}

Prosenttia BKT:sta

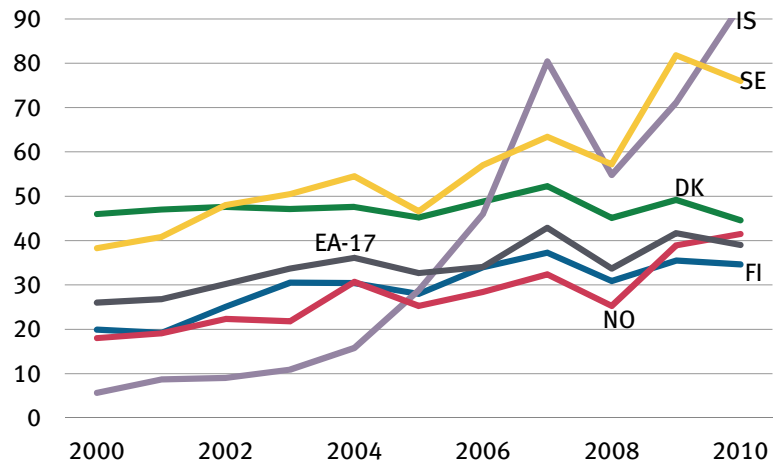

Dodi01. EA-17: 17 EU: $n$ jäsenvaltiota, jotka ovat ottaneet euron valuutaksi ainoana laillisena maksuvälineenä. 


\section{Talous}

\section{Bruttokansantuote henkeä kohti euroissa (PPP)}

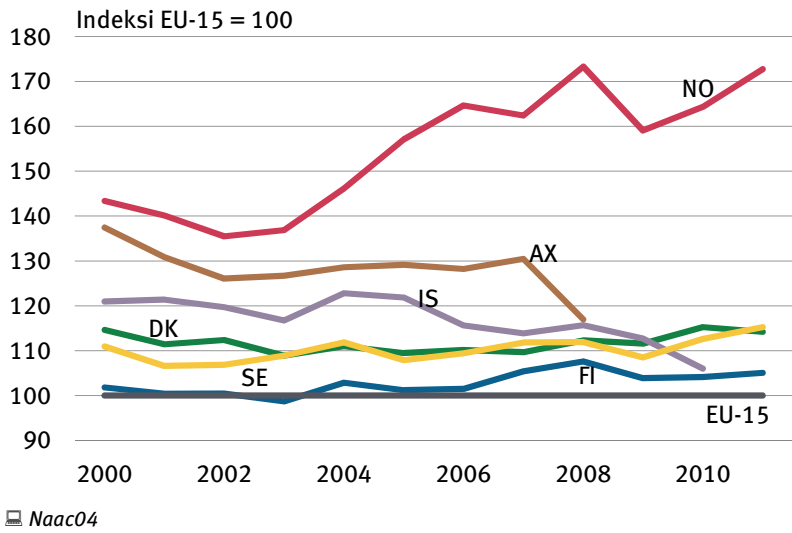

Bruttokansantuote, reaalinen vuosikasvu

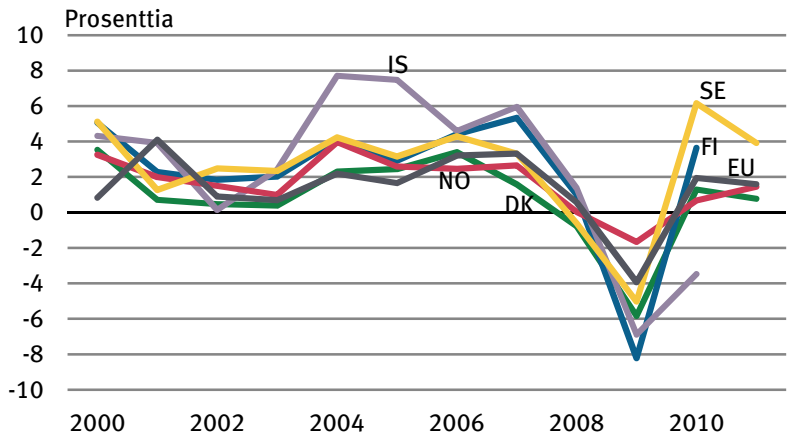

Naac04 ja Key01 
Pohjoismaiden vienti ja tuonti, eri maat ja alueet 2010

\begin{tabular}{|c|c|c|c|c|c|}
\hline Prosenttia & DK & FI & IS & NO & SE \\
\hline \multicolumn{6}{|l|}{ Vienti: } \\
\hline Yhteensä & 100,0 & 100,0 & 100,0 & 100,0 & 100,0 \\
\hline Pohjoismaat & 23,1 & 16,2 & 8,5 & 11,8 & 23,0 \\
\hline \multicolumn{6}{|l|}{ EU-15 (ei: Tanska, } \\
\hline Suomi ja Ruotsi) & 44,2 & 34,0 & 71,2 & 66,3 & 38,4 \\
\hline 12 uutta EU-maata & 5,7 & 7,4 & 3,0 & 3,1 & 5,8 \\
\hline Venäjä & 1,7 & 8,9 & 2,1 & 0,9 & 1,8 \\
\hline Muu Eurooppa & 2,2 & 3,7 & 2,9 & 1,3 & 2,7 \\
\hline Yhdysvallat ja Kanada & 7,4 & 8,2 & 5,0 & 6,6 & 8,3 \\
\hline Muu Amerikka & 2,4 & 2,5 & 0,4 & 1,2 & 2,5 \\
\hline Japani & 1,9 & 1,7 & 2,5 & 1,2 & 1,3 \\
\hline DAE-maat & 3,2 & 3,6 & 1,1 & 3,3 & 2,8 \\
\hline Kiina & 2,4 & 5,2 & 0,6 & 1,7 & 3,1 \\
\hline Intia & 0,5 & 1,2 & 0,1 & 0,3 & 1,2 \\
\hline Muu maailma & 5,3 & 7,5 & 2,6 & 2,2 & 9,2 \\
\hline \multicolumn{6}{|l|}{ Tuonti: } \\
\hline Yhteensä & 100,0 & 100,0 & 100,0 & 100,0 & 100,0 \\
\hline Pohjoismaat & 21,8 & 19,4 & 27,2 & 23,2 & 22,2 \\
\hline \multicolumn{6}{|l|}{ EU-15 (ei: Tanska, } \\
\hline Suomi, Ruotsi) & 48,4 & 39,5 & 29,9 & 33,7 & 45,5 \\
\hline 12 uutta EU-maata & 7,1 & 7,2 & 4,4 & 6,8 & 8,0 \\
\hline Venäjä & 1,1 & 17,6 & 0,6 & 2,6 & 4,9 \\
\hline Muu Eurooppa & 2,2 & 1,5 & 2,0 & 2,2 & 1,7 \\
\hline Yhdysvallat ja Kanada & 3,4 & 2,7 & 9,6 & 8,7 & 3,5 \\
\hline Muu Amerikka & 2,0 & 2,0 & 13,0 & 2,7 & 1,5 \\
\hline Japani & 0,4 & 0,7 & 2,3 & 2,2 & 1,7 \\
\hline DAE-maat & 3,3 & 2,1 & 1,8 & 5,7 & 3,3 \\
\hline Kiina & 7,2 & 4,4 & 6,0 & 8,5 & 5,0 \\
\hline Intia & 0,8 & 0,5 & 1,0 & 0,5 & 0,5 \\
\hline Muu maailma & 2,4 & 2,4 & 2,0 & 3,3 & 2,2 \\
\hline
\end{tabular}

Fotr49. DAE-maat (= kehittyvät Aasian taloudet) = Hongkong, Malesia, Singapore, Etelä-Korea, Taiwan ja Thaimaa. 


\section{Ulkomaankauppa}

Pohjoismaiden välinen tuonti ja vienti 2011

Prosenttia Pohjoismaiden välisestä kokonaistuonnista ja -viennistä 30

25

20

15

10

5

0

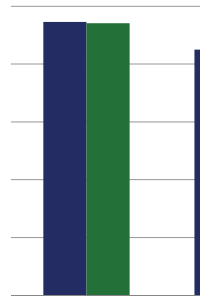

Tanska

$$
\begin{aligned}
& \text { Suomi } \\
& \text { Tuonti }
\end{aligned}
$$

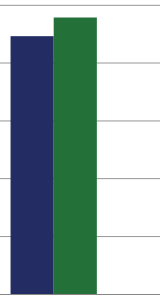

Islanti

Norja

- Vienti

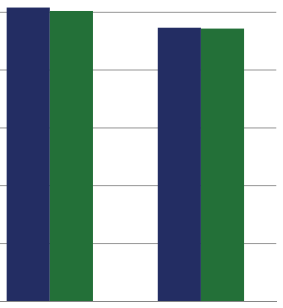

Ruotsi

마 Fotr49

\section{Kauppatase}

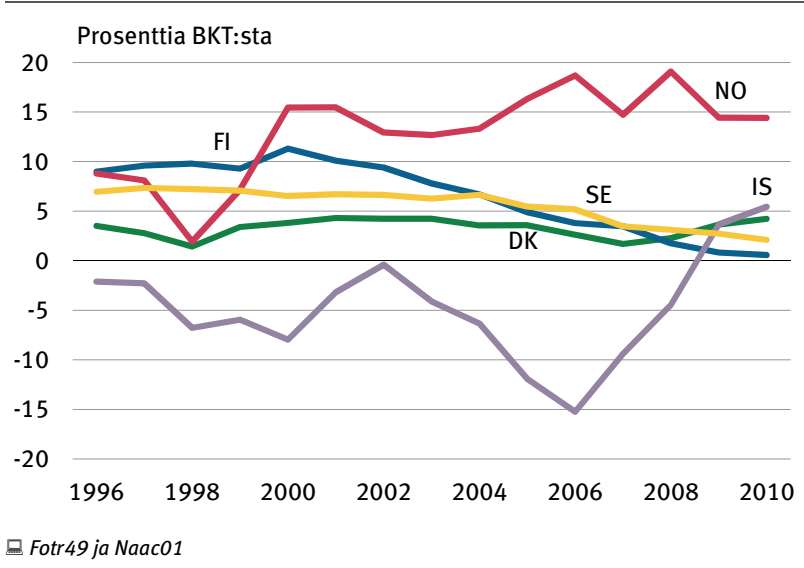


Julkinen talous ja hinnat

\section{Kuluttajahintaindeksi 2011}

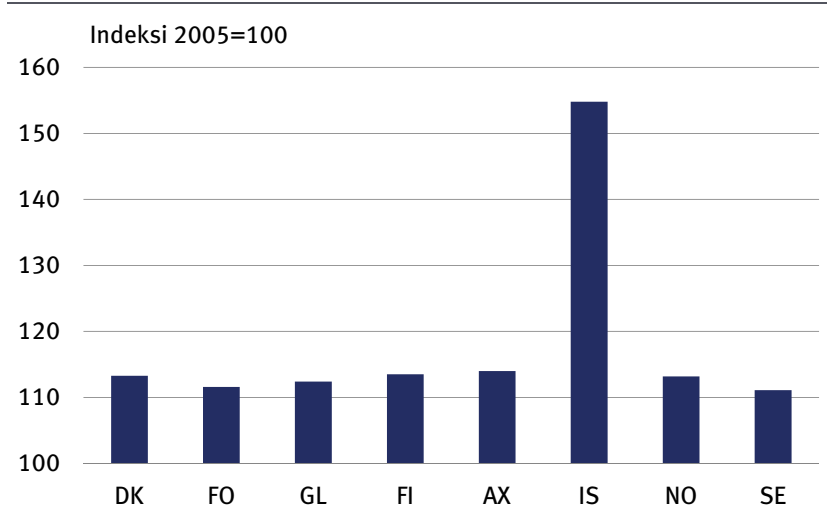

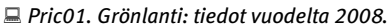

Hintataso 2011

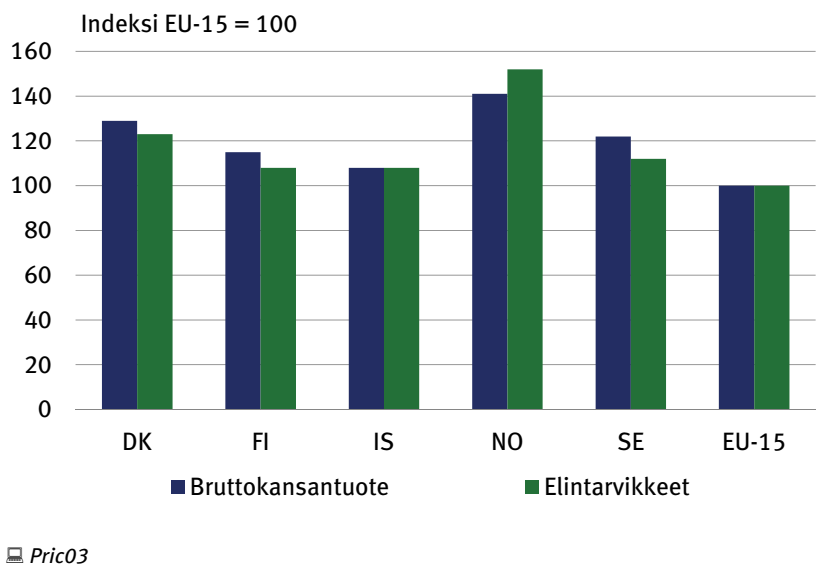


Julkinen talous ja hinna

Julkiset menot kohteen mukaan 2010

Prosenttia BKT:sta

80

30

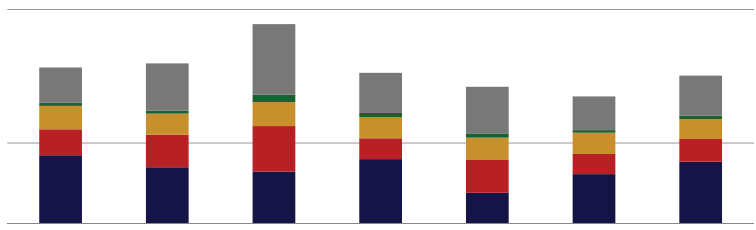

$-20$
DK
FO
GL $\quad \mathrm{Fl}$
IS
NO
SE
Koulutus, vapaa-ajan toiminta, kulttuuri ja uskonto
- Muut menot
- Oikeuslaitos, puolustus
- Terveydenhuolto
- Sosiaaliturva

@Pubs13. Grönlanti: tiedot vuodelta 2007.

\section{Julkisen talouden bruttovelka}

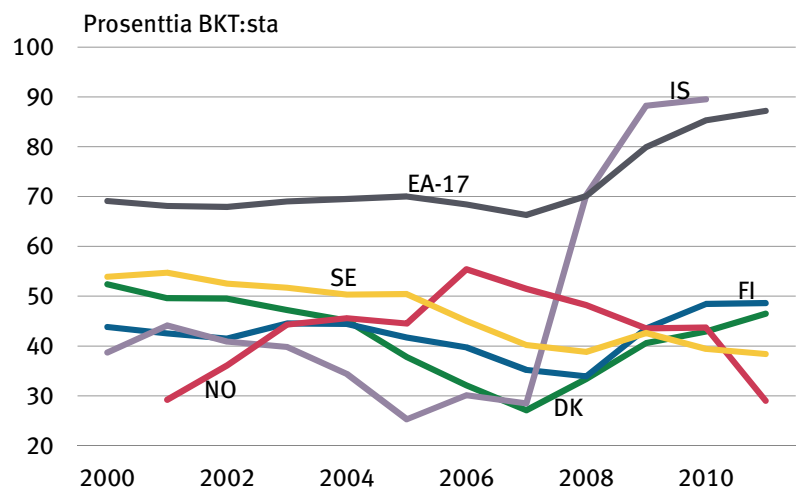




\section{Osakekurssit}

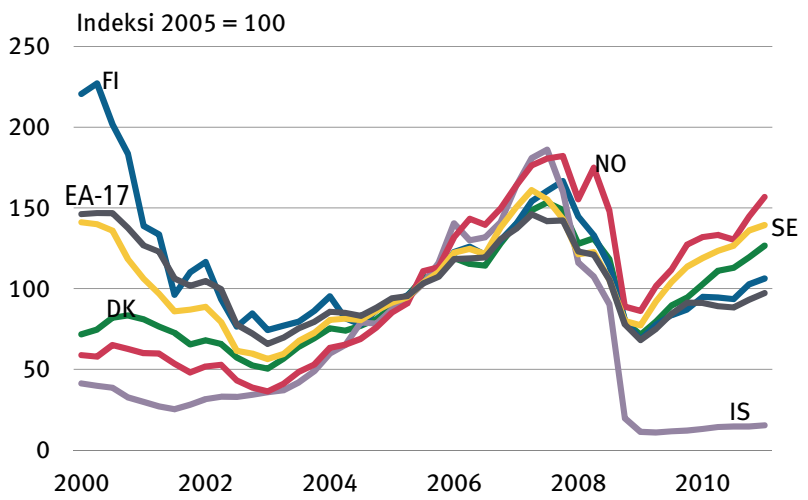

马har01

\section{Julkinen kehitysapu}

Prosenttia bruttokansantulosta (BKTL)

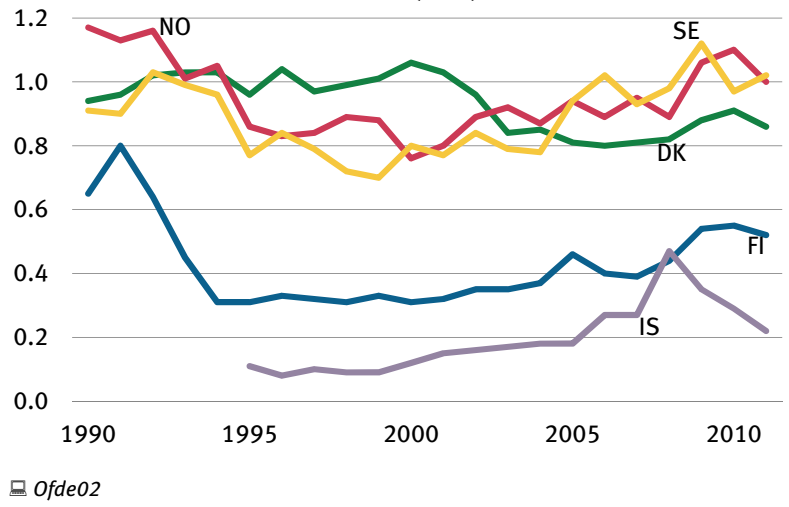


Tiede ja tekniikka

Tutkimus- ja kehittämistoiminnan menot sektoreittain 2010

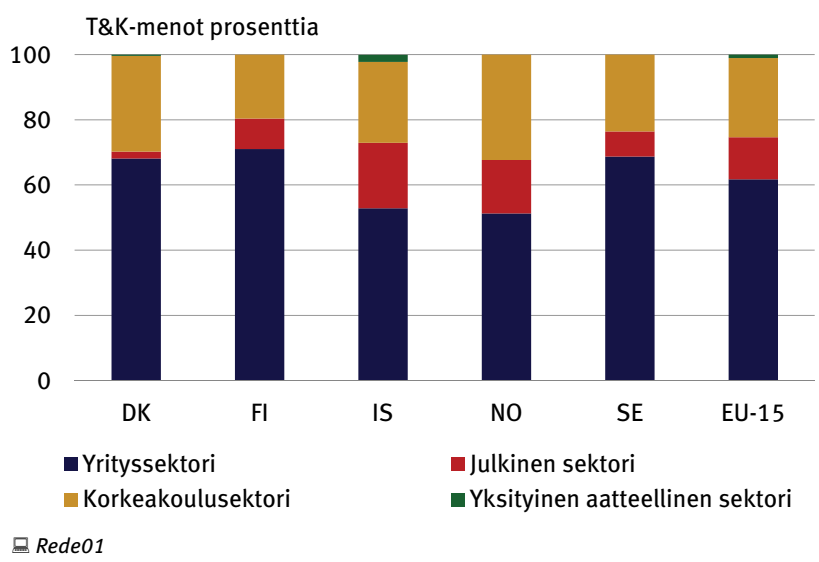

\section{Patentit 2011}

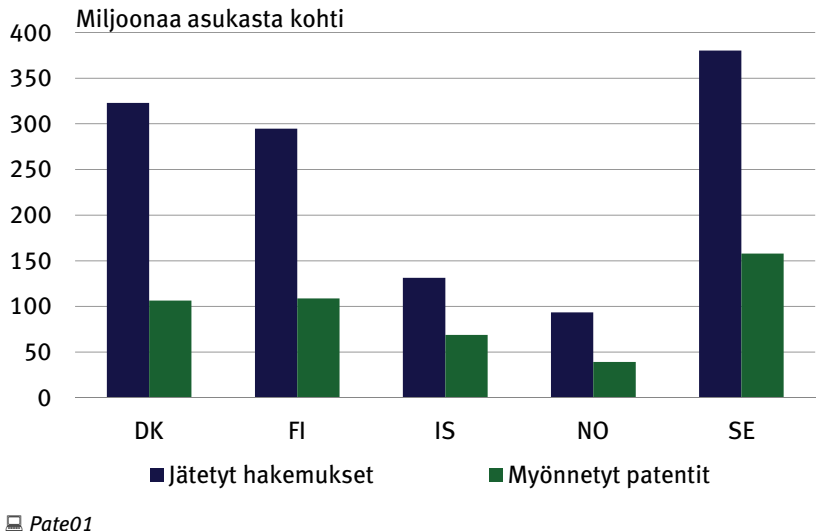


Filosofian tohtorit 2010

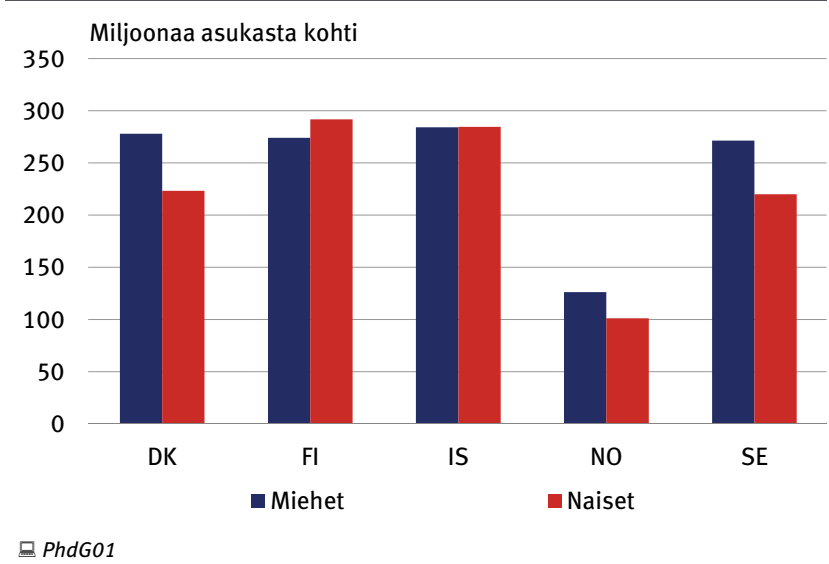

Yksityishenkilöiden verkko-ostokset

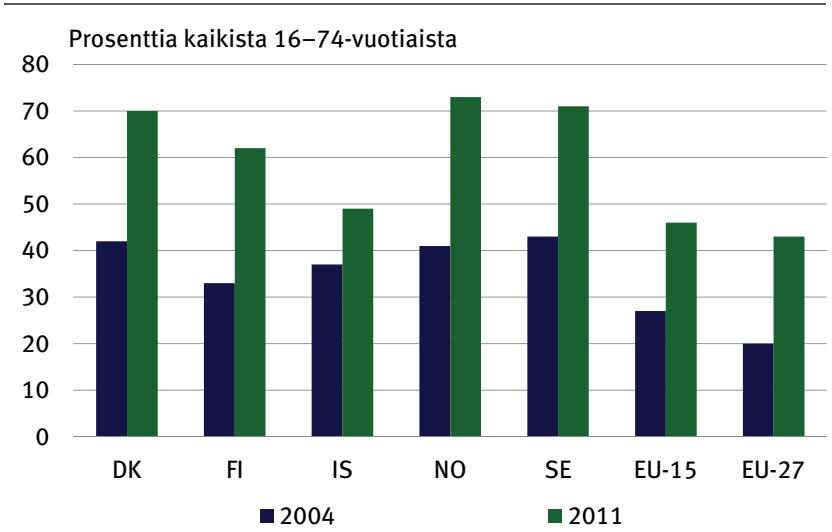

묘 Info13 
Tiede ja tekniikka

Yksityishenkilöiden asiointi julkisten viranomaisten kanssa internetissä 2011

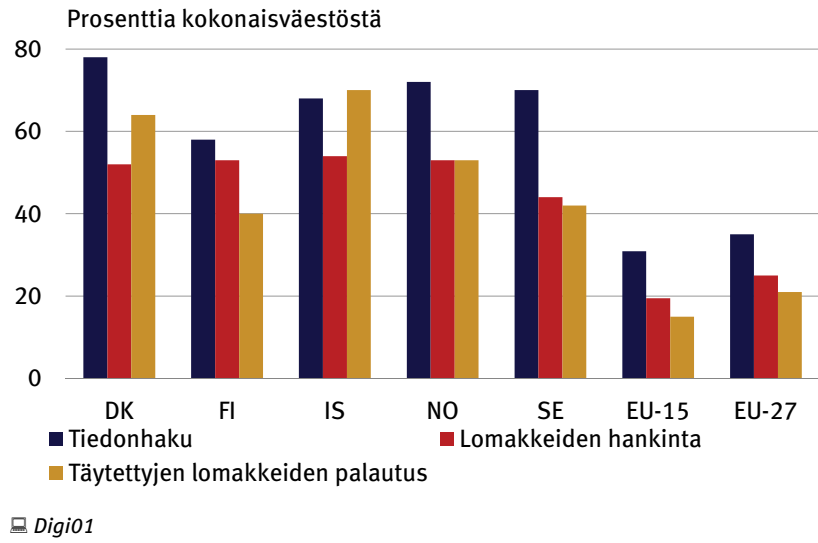

Yritysten asiointi julkisten viranomaisten kanssa internetissä 2011

Prosenttia kaikista yrityksistä

100

80

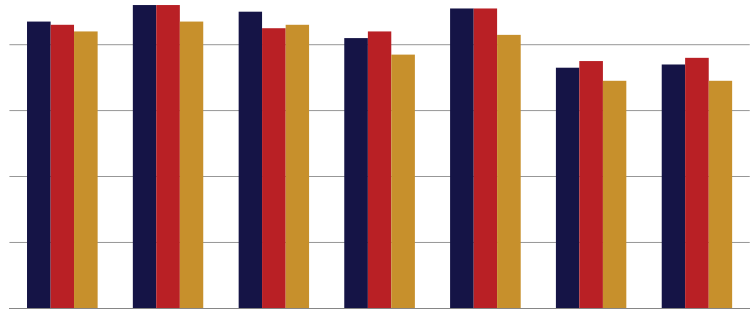

0

DK

$\mathrm{Fl}$

IS

- Tiedonhaku

NO

SE

EU-15

$\mathrm{EU}-27$

- Lomakkeiden hankinta

- Täytettyjen lomakkeiden palautus

\section{모잉}

